\title{
PEMBAGIAN PAKET SEMBAKO SEBAGAI BENTUK BANTUAN SOSIAL KEPADA PEKERJA JALANAN DI WILAYAH KELURAHAN CILENDEK TIMUR DALAM MASA TRANSISI PANDEMIK COVID-19
}

\section{DISTRIBUTION OF BASIC FOOD PACKAGES AS A FORM OF SOCIAL ASSISTANCE TO STREET WORKERS IN THE CILENDEK TIMUR VILLAGE DURING THE COVID-19 PANDEMIC TRANSITION}

\author{
Hanifah Puspita Nurul $\mathbf{H}^{\mathbf{1}}$, Anggi Senda Nikenindya ${ }^{1}$, Dhien Meutia Islamadina \\ Wulandani $^{1}$, Permata Aprilia Putri ${ }^{1}$, Cahya Ramadhanti Putri ${ }^{1}$, Zalfa Qanita ${ }^{1}$, \\ Almira Nadya Yasmine ${ }^{1}$, Saskia Ramadhanti ${ }^{1}$, Rangga Panengah $\mathbf{B}^{1}$, Zakiyatul \\ Faizah $^{2}$ \\ ${ }^{1}$ Mahasiswa, Kuliah Kerja Nyata Belajar Bersama Masyarakat, ${ }^{2}$ Dosen Pembina \\ Pembangunan Desa Lembaga Pengabdian Masyarakat, Universitas Airlangga \\ Kampus C UNAIR, Jln Mulyorejo, Surabaya Jawa Timur, Indonesia, 60115 \\ email: zakiyatul-fk@fk.unair.ac.id
}

\begin{abstract}
COVID-19 is a zoonotic disease that has the ability to transmit from animals to humans and transmission occurs through droplets, therefore the government appeal on people to carry out social distancing and quarantine. The purpose of this activity is to help food needs and facilitate the people who affected by COVID - 19 to be able to apply government program is Pola Hidup Bersih dan Sehat (PHBS) independently as an effort to prevent an increase in COVID - 19 cases. The implementation method is community service, starting with channeling social assistance in the form of distribution of groceries, hand sanitizers and liquid soap to the community around the streets of the City of Cilendek Timur, Bogor City. The results of this activity are a form of community service activities that are focused on one of the fields, namely the economic field, where the activities carried out in the form of providing social assistance by distributing nine basic goods or food to people in need.
\end{abstract}

Keywords: COVID-19, Social project, Social distancing, PHBS.

\section{abstrak}

COVID-19 merupakan penyakit zoonosis yang memiliki kemampuan menularkan dari hewan kepada manusia dan penularan terjadi melalui droplets, maka dari itu pemerintah menghimbau masyarakat untuk melakukan social distancing dan karantina. Tujuan dari kegiatan ini adalah membantu mencukupi kebutuhan pangan dan memfasilitasi masyarakat yang terdampak COVID - 19 untuk dapat menerapkan Perilaku Hidup Bersih dan Sehat (PHBS) secara mandiri sebagai upaya mencegah peningkatan kasus COVID - 19. Metode pelaksanaan adalah pengabdian masyarakat, dimulai dengan menyalurkan bantuan sosial dalam bentuk pembagian sembako, hand sanitizer dan sabun cair kepada masyarakat disekitar jalan Kelurahan Cilendek Timur Kota Bogor. Hasil dari kegiatan ini merupakan bentuk dari kegiatan pengabdian masyarakat yang difokuskan pada salah satu bidang yaitu bidang ekonomi, dimana kegiatan yang dilakukan diwujudkan dalam bentuk pemberian bantuan sosial dengan cara membagikan sembilan bahan pokok atau sembako kepada orang-orang yang membutuhkan.

Kata Kunci: COVID-19, Kegiatan sosial, Social distancing, PHBS. 


\section{PENDAHULUAN}

Indonesia tengah menghadapi pandemi COVID-19 dimana sejak Maret 2020 hingga saat ini telah tercatat lebih dari 100.000 penduduk Indonesia terinfeksi virus corona (Kompas.com). Berdasarkan data dari satgas COVID-19 melalui situs covid19.go.id, sebanyak lebih dari 4000 orang meninggal dunia akibat virus ini. Dalam situs covid19.go.id satgas COVID-19 juga menampilkan peta persebaran COVID-19 di Indonesia yang memperlihatkan bahwa virus corona sudah tersebar ke 34 provinsi dengan provinsi Jawa Barat menjadi salah satu dari 5 provinsi yang memiliki kasus terbanyak.

Virus corona tersebar ke wilayah-wilayah di Jawa Barat, tidak terkecuali Kota Bogor. Sebagai upaya mencegah persebaran COVID-19, pemerintah Kota Bogor telah memberlakukan kebijakan PSBB (Pembatasan Sosial Berskala Besar). Melansir Detik News, pemerintah Kota Bogor memutuskan mengakhiri Kebijakan PSBB dan memulai fase pra Adaptasi Kebiasaan Baru (AKB) atau new normal jalanan dalam membeli kebutuhan sehari-hari. Kemudian, tambahan hand sanitizer dan sabun cair dalam paket sembako diharapkan membantu para pekerja jalanan menerapkan PHSB.

Program bantuan sosial ini akan bermanfaat dalam membantu masyarakat yang membutuhkan seperti tukang sampah, pemulung, tukang sapu, dan lain sebagainya dalam menghadapi permasalahan ekonomi akibat kebijakan PSBB di Kota Bogor, khususnya di Jalanan Cilendek Timur dan sekitarnya.

Di masa new normal ini, masyarakat Kota Bogor kembali bekerja agar dapat pulih dari dampak PSBB. Pandemi COVID-19 yang menyebabkan pemerintah Kota Bogor memberlakukan kebijakan PSBB tentunya mempengaruhi perekonomian di Kota Bogor. Walaupun telah memasuki fase baru yakni new normal, masyarakat Kota Bogor masih berjuang untuk pulih dari dampak PSBB yang mempengaruhi perekonomian mereka. Pengaruh PSBB ini dirasakan oleh masyarakat Kota Bogor, tak terkecuali masyarakat menengah kebawah, salah satunya para pekerja jalanan seperti tukang sampah, pemulung, tukang sapu, dan lain sebagainya.

Berdasarkan permasalahan yang telah disebutkan, program bantuan sosial dirasa perlu dilaksanakan untuk membantu para pekerja jalanan seperti tukang sampah, pemulung, tukang sapu, dan lain sebagainya. Para pekerja jalanan banyak ditemui di jalanan Kelurahan Cilendek Timur dan sekitar. Untuk itu, bantuan sosial kami khususkan untuk mereka yang membutuhkan yakni para pekerja di jalanan Kelurahan Cilendek Timur dan sekitar berupa bantuan paket sembako yang ditambahkan dengan hand sanitizer dan sabun cair.

Bantuan sosial yang kami salurkan bertujuan untuk membantu mereka pulih dari dampak PSBB dan siap menghadapi new normal dengan menerapkan menerapkan PHBS (Perilaku Hidup Bersih dan Sehat). Paket sembako diharapkan berguna untuk meringankan beban para pekerja

\section{METODE PENGABDIAN MASYARAKAT}

Metode yang digunakan oleh kelompok kami dalam kegiatan KKN Mandiri ke-62 yang dilaksanakan pada tanggal 29 Juni - 25 Juli 2020 ini adalah dengan menggunakan 
metode pengabdian masyarakat yaitu dengan melakukan penyaluran bantuan sosial dalam bentuk sembako serta pembagian hand sanitizer dan sabun cair yang merupakan salah satu bentuk dukungan kelompok kami terhadap program pemerintah dalam mencegah peningkatan kasus penularan COVID-19 yaitu dengan membantu masyakarat kurang mampu khususnya para pekerja jalan seperti tukang sampah, pemulung, tukang bersih-bersih jalanan yang tersebar disekitar jalan Kelurahan Cilendek Timur dalam menerapkan Perilaku Hidup Bersih dan Sehat (PHBS). Untuk melaksanakan kegiatan pengabdian ini, maka tahapan yang dilakukan sebagai berikut:

1. Studi pendahuluan, dilakukan untuk mengetahui keadaan riil masyarakat untuk dijadikan kelompok sasaran kegiatan pengabdian yang meliputi kondisi sosialekonomi. Observasi ini dilakukan agar pembagian sembako dapat tersebar secara merata.

2. Persiapan, pada tahap ini tim pelaksana menyiapkan segala keperluan yang dibutuhkan dalam pelaksaan pembagian sembako serta sabun cair dan hand sanitizer yaitu bahan-bahan yang dibutuhkan dalam sembako seperti beras, minyak goreng, mie instan, susu kental manis serta sabun cair dan hand sanitizer. Serta dilanjut dengan proses pengemasan bahan-bahan tersebut ke dalam satu plastik agar lebih mudah untuk didistribusikan.

3. Pendistribusian, pada tahap ini tim pelaksana melakukan pendistribusian kepada sasaran yang telah ditetapkan sebelumnya yaitu pekerja jalan seperti pemulung, tukang bersih-bersih, tukang sampah, dan lainnya yang membutuhkan yang tersebar di sekitar jalan di daerah kelurahan Cilendek Timur.

\section{HASIL DAN PEMBAHASAN}

Hasil dari kegiatan ini merupakan bentuk dari kegiatan pengabdian masyarakat yang difokuskan pada salah satu bidang yaitu bidang sosial ekonomi, dimana kegiatan yang dilakukan diwujudkan dalam bentuk pemberian bantuan sosial dengan cara membagikan sembilan bahan pokok atau sembako kepada orang-orang yang membutuhkan. Kegiatan distribusi sembako ini sendiri telah dilaksanakan selama dua hari yaitu pada tanggal 15 dan 17 Juli 2020 di daerah kelurahan Cilendek Timur, Kota Bogor dan sekitarnya. Dengan kronologi pelaksanaan sebagai berikut:

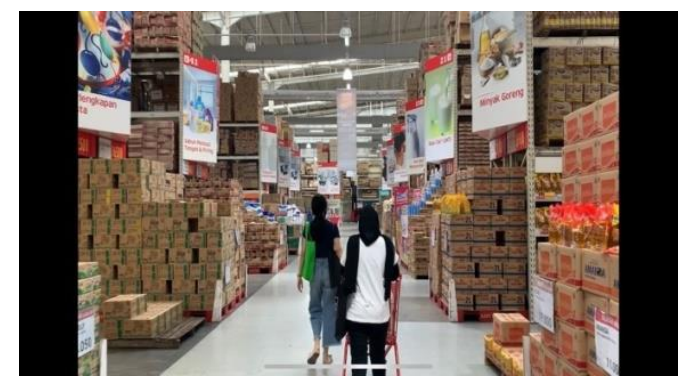

Gambar 1 Proses belanja sembako

Pada Rabu, 15 Juli 2020, kegiatan diawali dengan membeli bahan-bahan makanan atau sembako, sabun cuci cair dan pembersih tangan (hand sanitizer) di pusat perbelanjaan terdekat, yang nantinya ini akan dibagikan kepada orang-orang yang membutuhkan di beberapa daerah di Kota Bogor. Bantuan sosial yang diberikan terdiri dari beras, mie 
instan, minyak goreng dan susu kental manis. Serta diberikan pula sabun cair dan pembersih tangan (hand sanitizer), dengan tujuan agar masyarakat yang mendapatkan bantuan sosial dapat menerapkan PHSB (Perilaku Hidup Bersih dan Sehat) yang sesuai dengan anjuran Kementerian Kesehatan Republik Indonesia dalam GERMAS (Gerakan Masyarakat Hidup Sehat) (Kemkes, 2020).

Dalam melakukan pendistribusian bantuan sosial berupa sembako ini kami menggunakan pendekatan partisipatif. Pendekatan partisipatif menekankan kepada pengumpulan data dan proses pelaksanaan yang melibatkan langsung peranan peneliti, dengan cara melihat fenomena secara lebih luas dan akan disesuaikan dengan kondisi sosial masyarakat yang tengah diteliti (Rahman, 2019). Pendistribusian sembako ini didasarkan pula kepada kondisi terkini masyarakat Kota Bogor yang terkena dampak wabah virus COVID-19, utamanya kepada para pekerja jalanan yang harus tetap turun ke jalan ditengah kondisi seperti sekarang ini.

Proses pendistribusian bantuan sosial berupa sembako ini kami laksanakan di jalan-jalan utama yang lokasinya dekat dengan jangkauan kami, yaitu seperti di Jln. Yasmin Raya, Kelurahan Cilendek Timur, Jln. Ahmad Yani, daerah Tamansari dan Bukit Cimanggu City, Kota Bogor.

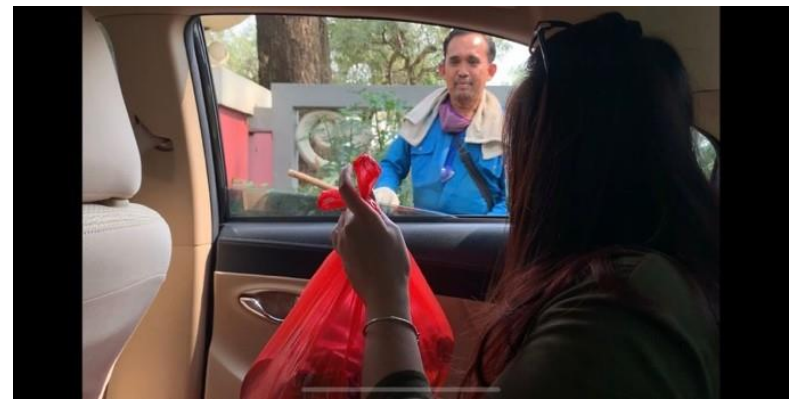

Gambar 2 Proses distribusi sembako tahap 1

Proses distribusi sembako tahap 1 kami laksanakan pada hari Rabu, 15 Juli 2020 di sekitar Jln. Ahmad Yani, Kota Bogor.

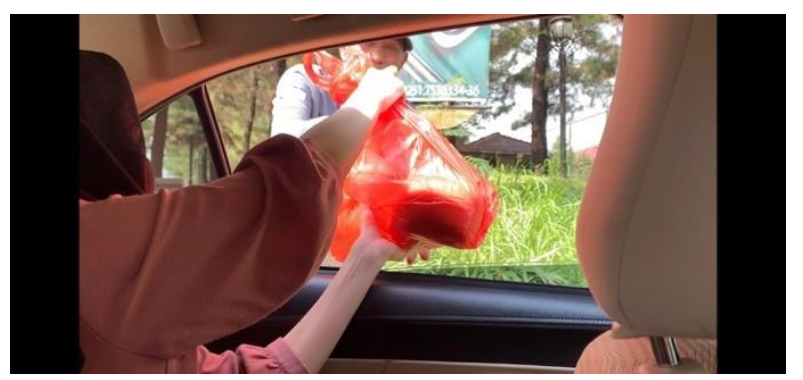

Gambar 3 Proses distribusi sembako tahap 2

Proses distribusi sembako tahap kedua kami laksanakan pada hari Jum'at tanggal 17 Juli 2020 pada dua tempat berbeda, pada sesi awal kami membagikan sembako tahap 2 di sekitar Jln. Yasmin Raya, Kelurahan Cilendek Timur, Kota Bogor. 


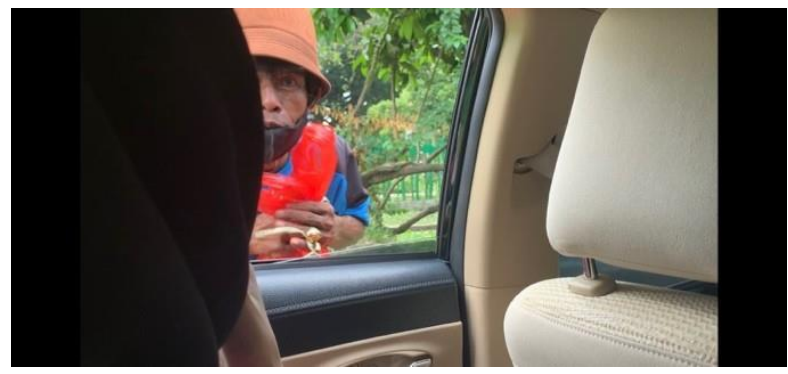

Gambar 3.1 Proses distribusi sembako tahap 2

Masih di hari yang sama, pada sesi kedua distribusi sembako tahap 2 kami lakukan di sekitar daerah Tamansari dan Bukit Cimanggu City, Kota Bogor. Pembagian bantuan sosial berupa sembako tersebut bertujuan untuk meringankan dan membantu mencukupi kebutuhan pangan bagi orang-orang terkena dampak Covid-19. Pembagian sembako dari dalam mobil menjadi salah satu alternatif yang kami gunakan di kala pandemi Covid-19 karena hal ini dianggap lebih efisien, disamping itu pembagian sembako dari dalam mobil dapat mengantisipasi adanya potensi paparan Covid-19 secara langsung. Kami mengaitkan program kerja distribusi

sembako ini dengan pendekatan partisipatif karena saat proses distribusi berlangsung, kami langsung turun ke jalan dan membagikan sembako melalui jarak yang aman. Sehingga dapat disimpulkan bahwa ada proses interaksi langsung antara kami sebagai penyalur dengan pihak-pihak yang membutuhkan, dan dapat kami dipastikan bahwa sembako yang dibagikan memang tersalurkan dengan baik dan sesuai dengan target awal kami. Dengan adanya pemberian bantuan sosial ini diharapkan dapat memberikan keringanan serta meningkatkan manfaat kepada penerima bantuan itu sendiri.

Setelah itu, anggota KKN-BBM 62 Universitas Airlangga Kelompok 264 turut membuat video laporan terkait distribusi sembako sebagai bentuk pemberitahuan dan penyampaian atas kronologis selama program berlangsung. Hasil video yang kami buat kemudian diunggah pada laman Instagram dan Youtube Kelompok 264. Video yang dibuat diunggah pada laman Youtube Kelompok KKN BBM-62 Universitas Airlangga agar bertujuan untuk menarik perhatian masyarakat agar dapat tergerak lalu ikut membantu dan berbagi kepada orang- orang yang lebih membutuhkan.

\section{PENUTUP}

\section{Simpulan}

Kasus COVID-19 di Indonesia yan terus menerus meningkat dari waktu ke waktu mengakibatkan sector perekonomian mengalami ketidakstabilan sehingga menyebabkan inflasi dimana-mana. Harga bahan pokok dan sembako relatif menjadi lebih tinggi dibandingkan sebelumnya. Hal ini menyebabkan daya beli masyarakat akan bahan pangan menjadi lebih rendah.

Oleh karena itu bantuan sosial diperlukan untuk meringankan beban masyarakat sehingga dapat memperoleh pangan secara layak walaupun dalam keadaan sulit akibat dampak dari pandemi COVID -19. Bantuan sosial juga diberikan dalam bentuk hand sanitizer dan sabun cuci cair sebagai upaya kami dalam mencegah penambahan kasus 
COVID-19 dan memfasilitasi masyarakat akan pentingnya untuk melakukan pola hidup bersih dan sehat (PHBS) secara mandiri.

\section{Saran}

Edukasi masyarakat mengenai pentingnya untuk menjaga kebersihan diri, lingkungan, dan pola makan masih terus harus dilakukan, selain itu pengadaan pangan (sembako) dengan harga terjangkau di semua kalangan khususnya kalangan menengah kebawah dan stabil perlu diterapkan melihat ketidakmerataan kesejahteraan yan terjadi.

\section{DAFTAR PUSTAKA}

Detik.com. 2020. PSSB Transisi Berakhir Kota Bogor Masuk Fase Uji Coba New Normal. Di akses dari : https://news.detik.com/berita-jawa-barat/d5077186/psbb-transisi-berakhir-kota-bogor-masuk- fase-uji-coba-new-normal pada 28 Juli 2020.

Direktorat Jenderal Pencegahan dan Pengendalian Penyakit. 2020. Pedoman Kesiapsiagaan Menghadapi Infeksi Novel Corona Virus (2019 - nCoV). Jakarta : Kemekes RI.

Kemkes, 2020. Perilaku Hidup Bersih dan Sehat.Diakses dari: http://promkes.kemkes.go.id/ pada 28 Juli 2020.

Kompas.com. 2020. Kini Ada 102.051 Kasus Covid-19 di Indonesia, Bertambah 1.748. Diakses dari : https://nasional.kompas.com/read/2020/07/28/15283601/updatekini-ada-102051-kasus-covid-19-di- indonesia-bertambah-1748 pada 28 Juli 2020.

Rahman, Arief. 2019. Pendekatan Partisipatif dalam Pengembangan Komunitas. Modul Pengembangan Komunitas. Bogor: Program Perencanaan dan Pengembangan Komunitas P4W-LPPM Institue Pertanian Bogor.

Suni, Nur Sholikah Putri. 2020. Kesiapsiagaan Indonesia Menghadapi Potensi Penyebaran Corona Virus Disease. Journal Bidang Kesejahteraan Sosial, 7(3), 13 - 18. 